\title{
Abuse of Prescription Drugs in the Context of Novel Psychoactive Substances (NPS): A Systematic Review
}

\author{
Fabrizio Schifano, Stefania Chiappini * (1), John M. Corkery and Amira Guirguis \\ Psychopharmacology, Drug Misuse and Novel Psychoactive Substances Research Unit, School of Life and \\ Medical Sciences, University of Hertfordshire, Hertfordshire AL10 9AB, UK; f.schifano@herts.ac.uk (F.S.); \\ j.corkery@herts.ac.uk (J.M.C.); a.guirguis2@herts.ac.uk (A.G.) \\ * Correspondence: stefaniachiappini9@gmail.com; Tel.: +44-(0)1707-281053
}

Received: 27 March 2018; Accepted: 20 April 2018; Published: 22 April 2018

\begin{abstract}
Recently, a range of prescription and over-the-counter drugs have been reportedly used as Novel Psychoactive Substances (NPS), due to their potential for abuse resulting from their high dosage/idiosyncratic methods of self-administration. This paper provides a systematic review of the topic, focusing on a range of medications which have emerged as being used recreationally, either on their own or in combination with NPS. Among gabapentinoids, pregabalin may present with higher addictive liability levels than gabapentin, with pregabalin being mostly identified in the context of opioid, polydrug intake. For antidepressants, their dopaminergic, stimulant-like, bupropion activities may explain their recreational value and diversion from the therapeutic intended use. In some vulnerable clients, a high dosage of venlafaxine ('baby ecstasy') is ingested for recreational purposes, whilst the occurrence of a clinically-relevant withdrawal syndrome may be a significant issue for all venlafaxine-treated patients. Considering second generation antipsychotics, olanzapine appears to be ingested at very large dosages as an 'ideal trip terminator', whilst the immediate-release quetiapine formulation may possess proper abuse liability levels. Within the image- and performanceenhancing drugs (IPEDs) group, the beta-2 agonist clenbuterol ('size zero pill') is reported to be self-administered for aggressive slimming purposes. Finally, high/very high dosage ingestion of the antidiarrhoeal loperamide has shown recent increasing levels of popularity due to its central recreational, anti-withdrawal, opiatergic effects. The emerging abuse of prescription drugs within the context of a rapidly modifying drug scenario represents a challenge for psychiatry, public health and drug-control policies.
\end{abstract}

Keywords: drug abuse; novel psychoactive substances; NPS; pharmacovigilance; prescribing drugs' abuse

\section{Introduction}

Novel Psychoactive Substances (NPS; 'legal highs' or 'research chemicals') are molecules designed to mimic the effects of legal traditional recreational drugs with intense psychoactive effects and virtual non-detectability in routine drug screenings. NPS include synthetic cannabinoids, cathinone derivatives, psychedelic phenethylamines, novel stimulants, synthetic opioids, tryptamine derivatives, phencyclidine-like dissociatives, piperazines, psychoactive plants/herbs and a range of prescribed medications [1]. The term NPS was first used by United Nations Office on Drugs and Crime (UNODC) to refer to "substances of abuse, either in a pure form or a preparation, that are not controlled by the 1961 Single Convention on Narcotic Drugs or the 1961 Convention on Psychotropic Substances, but which may pose a public health threat" [2]. At present, the emergence of NPS, typically from outside Western countries [3], represents a considerable public health challenge. Moreover, in order to circumvent the present controls and regulations, NPS are constantly diversifying 
and being replaced [4]. This is being facilitated by the growing number of anonymous online marketplaces, called 'cryptomarkets', which host many anonymous sellers whilst using untraceable cryptocurrencies [5]. NPS users report a range of reasons behind their preference for NPS as opposed to traditional drugs such as cannabis, cocaine and heroin, including typical lack of detectability, greater affordability, lack of stigma, and relative ease of online acquisition [6]. Recently, however, the phenomenon of using prescription drugs in an idiosyncratic way to resemble, or counteract, the effects of NPS, has increasingly been described. This phenomenon refers not only to high potency opioids (e.g., fentanyl) and 'exotic' / designer benzodiazepines-molecules already having been reported to be addictive [1] — but also: gabapentinoids [7], a range of stimulants [1], antipsychotics [8], antidepressants [9] and image- and performance-enhancing drugs (IPEDS, e.g., anabolic steroids, vitamins, clenbuterol and salbutamol) [10]. Among over-the-counter drugs, the two most common agents reportedly ingested in intentional abuse cases are the antitussive, dextromethorphan [11], and loperamide, a common antidiarrhoeal drug [12].

Any pharmacovigilance approach aims to detect, assess, understand and hopefully prevent adverse effects or any other medicine-related problems. From this point of view, there is a growing attention on prescription drugs and their addictive liability levels/diversion potential $[7,8,10,12]$. As the intended and the actual use of medicines differ between clinical trials and real-world use, pharmacovigilance activities are well placed to focus on the post-marketing phase. In Europe, those activities are coordinated by the European Medicines Agency (EMA) [13] through EudraVigilance (EV), which is the system for collecting, managing and analyzing information on suspected adverse reactions to medicines which have been authorized in the European Economic Area (EEA) [14].

This paper aims to provide a systematic review of the available literature relating to a preselected range of prescription medicines (pregabalin, gabapentin, quetiapine, olanzapine, venlafaxine, bupropion, loperamide, clenbuterol and salbutamol) previously reported as possibly being misused as NPS. For each molecule, a range of preclinical, epidemiological, and clinical pharmacological data will be provided.

\section{Materials and Methods}

A systematic review was carried out, consistent with the Preferred Reporting Items for Systematic Reviews and Meta-Analysis (PRISMA) guidelines [15]. A literature search was performed on PubMed, Medline/OvidSP (includes Embase), and Web-of-Science; the current search was completed in February 2018 and was not associated with any time restrictions. We focused on pregabalin, gabapentin, quetiapine, olanzapine, venlafaxine, bupropion, clenbuterol, salbutamol and loperamide [Title/Abstract]. For each molecule, a number of search terms [Title/Abstract] were considered as follows: 'misuse', 'abuse', 'dependence', 'withdrawal', 'off-label use' and 'non-medical use'. In addition, the authors performed further secondary searches by using the reference listing of all eligible papers. All titles/abstracts were examined, and full texts of potentially relevant papers obtained. Relevant works were selected in order to obtain a full representation of the available literature data on the selected topic. Eligible studies were identified if they possessed a range of characteristics, including (1) peer-reviewed clinical/human studies; (2) at least an abstract with estimates and/or full availability of results; and (3) focusing on the misuse/abuse/dependence/withdrawal of pregabalin; gabapentin; quetiapine; olanzapine, venlafaxine, bupropion, loperamide, clenbuterol and salbutamol. The entire range of literature papers were included, e.g., experimental and observational studies; case reports; case series; and fatalities' reports. Although letters to the editor, conference proceedings, and book chapters were excluded from the systematic review, they were still considered in the retrieval of further secondary searches. SC independently extracted and collected relevant data; FS contributed to the analysis of the results and discussed possible issues and disagreements during the revision of the paper with SC.

From an initial list of 171 studies, 151 were identified as relevant and appropriate in terms of quality according to PRISMA checklists. Following this, duplicates, papers lacking an English abstract, letters to the editor, animal studies and papers unrelated to the topic were excluded, and 128 papers 
were finally considered for the current study. A flow diagram (Figure 1) describes the reasons for study inclusion/exclusion at each stage, is here provided.

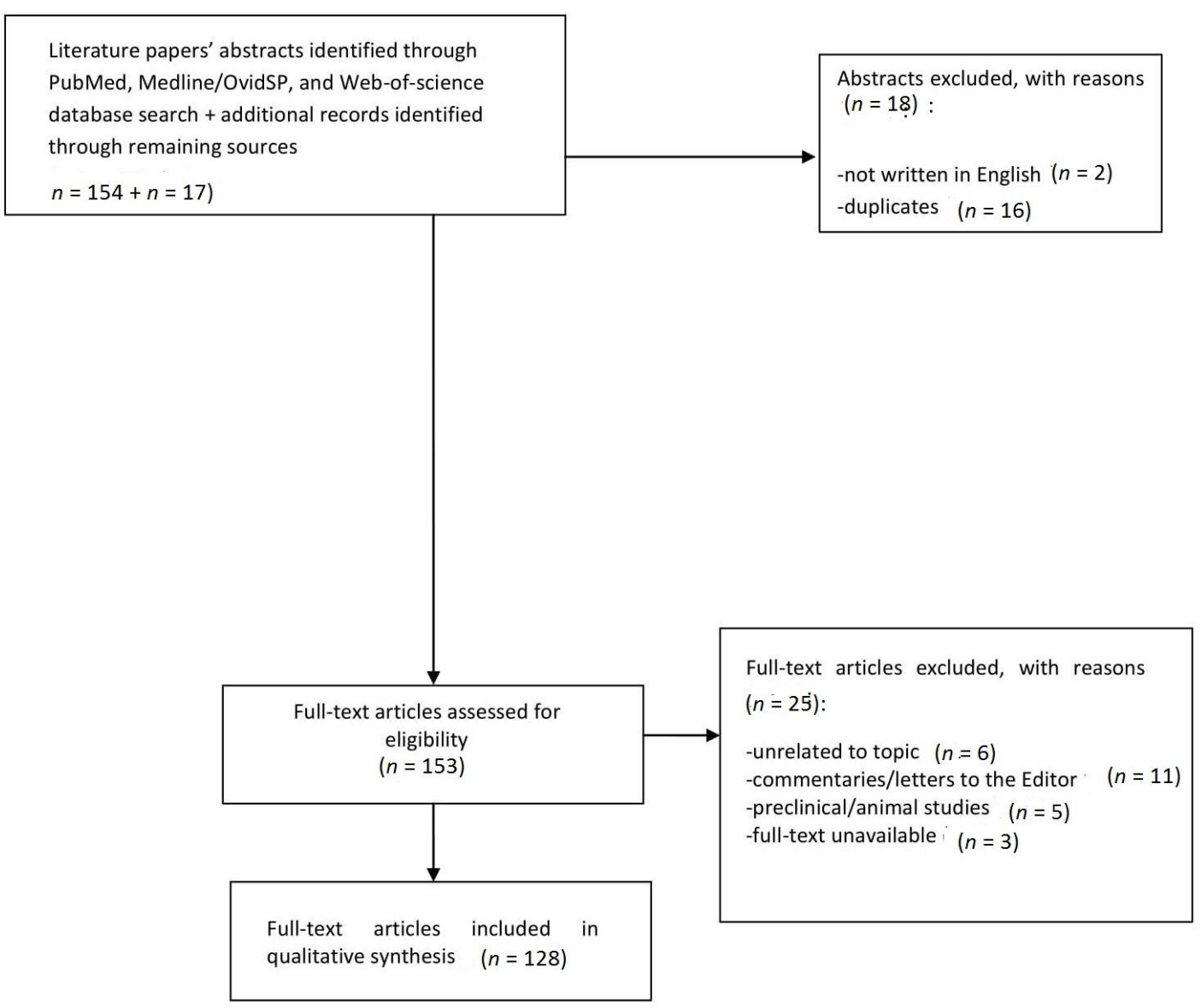

Figure 1. Selection of retrieved studies.

\section{Results}

\subsection{Gabapentinoids}

Recently, the gabapentinoids, pregabalin and gabapentin, have increasingly been reported to be abused at the EU-wide level, in parallel with increasing levels of prescriptions, related fatalities and a growing black market [16-19]. Gabapentinoids are anticonvulsants but are also prescribed for a range of clinical conditions in neurology, psychiatry and rheumatology, whilst being used off-label for the treatment of benzodiazepine and alcohol dependence. Their effects are the result of calcium channel binding, resulting in decreased central excitability levels. Compared to gabapentin, pregabalin's binding affinity and potency are six times higher; pregabalin's more significant misuse potential may also be due to its more rapid absorption, faster onset of action, much faster attainment of maximum plasma concentration and higher bioavailability ( $>90 \%$, irrespective of the dosage). Furthermore, gabapentinoids are thought to possess GABA-mimetic properties, whilst possibly having direct/indirect effects on the dopaminergic 'reward' system [7]. Gabapentionoid web enthusiasts report the ingestion of this compound alone or in combination with other drugs (e.g., cannabis, alcohol, opioids and other prescribed drugs), at a dosage range of 1000-4800 $\mathrm{mg}$ for gabapentin [20], and 750-12,000 mg for pregabalin [7]. Typical psychoactive effects include a sense of well-being/relaxation, euphoria, and even hallucinations [1]. In 2005, the Drug Enforcement Administration (DEA) placed pregabalin into Schedule V of the Controlled Substances Act (CSA) because of its potential for abuse [21] and a similar scheduling approach has recently been approved in the UK. Chiappini 
and Schifano [7] recently assessed the EMA EV database of pregabalin and gabapentin misuse-related Adverse Drug Reactions (ADRs) over the last decade. According to the Proportional Reporting Ratio (PRR) computation, abuse/dependence issues were more frequently reported for pregabalin compared with gabapentin, hence confirming its higher addictive liability levels [7,22]. Furthermore, Emergency Department presentations involving intentional drug overdoses recorded by the National Self-Harm Registry (Ireland; 2007-2015), showed that gabapentinoids have been increasingly identified over time, with high dosages and polydrug abuse being reported [23]. Indeed, gabapentinoid fatalities are typically observed when these molecules are associated with other psychoactive drugs, especially opioids and other sedatives whose effects are potentiated by gabapentinoids [24,25].

\subsection{Antidepressants}

Consistent with a worldwide rise in antidepressant consumption [26,27], bupropion and venlafaxine have anecdotally emerged as increasingly being abused $[1,28,29]$. In examining a range of online communities and specialized web services, several antidepressant misusers' experiences may be identified [20]. These reports emphasise both bupropion's stimulant effects and venlafaxine's dissociative properties. Indeed, bupropion described as being ingested in very large quantities (up to $4050 \mathrm{mg} /$ day, roughly 14 times higher than the maximal therapeutic dosage) in order to achieve an 'amphetamine-like high' [30]. In most abuse cases, its recreational use is associated with oral or nasal administration, but intravenous use has also been reported [28,30-34]. Bupropion pharmacology relies on its action both as a selective inhibitor of catecholamines (noradrenaline and DA) reuptake [35,36], and as a non-competitive antagonist of nicotinic acetylcholine receptors, hence being prescribed as well as an aid in smoking cessation [36]. Bupropion is known to be a cathinone derivative, that is, a beta-ketone amphetamine analogue with dopaminergic and noradrenergic effects, which may explain its misuse potential $[37,38]$. This is a reason for concern since bupropion is also used 'off-label' in a range of conditions, including attention-deficit/hyperactivity disorder, chronic fatigue, sexual dysfunction, and obesity. The adverse effects of bupropion misuse range from nasal pain to irritability, agitation, cardiac toxicity, hallucinations and seizures [39,40]. A retrospective review [41] on bupropion cases of intentional abuse reported to the US National Poison Data System highlighted an increase of $75 \%$ from 2000 to 2012, with the typical effects reported including tachycardia, seizures, agitation/irritability, hallucinations/delusions, and tremor; similar data were identified by the Toxicology Data Network of the US National Institute of Health (Toxnet) [42]. Typical bupropion abusers may present with a history of drug addiction $[38,43,44]$ and/or are inmates, with bupropion having been removed from some US prison formularies [45-47]. Conversely, venlafaxine is a selective serotonin-norepinephrine reuptake inhibitor (SNRI) antidepressant, indicated [48] for the treatment of major depressive episodes, generalised anxiety disorder and social phobia, with off-label use including obsessive-compulsive disorder and chronic pain syndromes. Its reuptake effects are dose-dependent, with action progressively including serotonin (5-HT), norepinefrine (NE) and dopamine (DA). Venlafaxine's main active metabolite, desvenlafaxine, is highly inhibitive of NE transporter activities, further increasing the rate of DA turnover in the prefrontal cortex [49]. Both venlafaxine and its metabolite are not associated with monoamine oxidase inhibitory activity, which is responsible for the degradation of DA. Hence, venlafaxine abuse may be associated with DA increase in the prefrontal cortex [50], high affinity for D2 receptors adaptive changes in D3 receptors following its chronic administration and, finally, with the desensitisation of both 5-HT1A and beta-adrenergic receptors [51]. Dependence and withdrawal symptoms associated with both SSRIs and SNRIs have already been described, specifically with abrupt discontinuation of venlafaxine (including Extended Release (XR) formulation) after long-term use [9,52-54]. Symptoms range from mild to severe and include nausea, depression, suicidal thoughts, disorientation, stomach cramps, panic attacks, sexual dysfunction, headaches and occasional psychotic symptoms [55-59]; a newborn discontinuation syndrome has been described as well, at times associated with encephalopathy or paroxysmal episodes [60]. The management of venlafaxine withdrawal includes the use of other antidepressants 
(Ads) or venlafaxine tapering doses [61,62]. Furthermore, venlafaxine/'baby ecstasy' abuse has been reported, typically being the result of the intake of very large doses [63-65]. Consistent with this, studies have assessed drug and pharmaceutical consumption in England through wastewater analysis and comparing it to NHS prescription statistics. Discrepancies have been observed in the case of venlafaxine, suggesting sales of non-prescribed venlafaxine, which are, therefore, not included within NHS data [66]. Furthermore, in a retrospective review of the records of the New Zealand National Poisons Centre over the period 2003-2012, rapidly increasing levels of enquiries were identified for a range of prescription medicines, including venlafaxine [67]. According to the EMA EV database from the last decade [68], the misuse-/abuse-/dependence- and withdrawal-related ADRs reported respectively for bupropion and venlafaxine show that bupropion may possess a higher recreational value due to its dopaminergic and stimulant-like activity, whilst the occurrence of a venlafaxine-withdrawal syndrome may be a significant issue for venlafaxine-treated patients; these data were confirmed by analysis of the UK-based Yellow Card Scheme [68].

\subsection{Antipsychotics}

Consistent with their increased prescription and availability [69], second-generation antipsychotic (SGA) (e.g., quetiapine and olanzapine) abuse has recently been reported [1,70-72]. Quetiapine appears to be the most documented SGA being abused; it is commonly administered in the $400-800 \mathrm{mg} /$ day range for the treatment of schizophrenia; bipolar disorder; and as an add-on in major depression and anxiety [73-76]. Quetiapine is anecdotally known as 'Susie Q'; 'Quell'; and 'baby heroin' [75-79], with 'Q ball' and 'Maq ball', respectively, being combinations with cocaine, and marijuana. Crushed quetiapine tablets can be self-administered through nasal insufflation [79-81], although both oral [81-84], and intravenous [85-87] routes of administration have been reported. Consistent with these anecdotal clinical observations, post-marketing surveillance reports indicate an increase in quetiapine availability on the black-market [75,79,88-90]. Furthermore, quetiapine, either on its own or in combination with heroin and/or alcohol [91], is consistently associated with high rates of ambulance attendances, indicating greater community-level harm relative to other atypical antipsychotics [92]. Indeed, between 2005 and 2011, quetiapine-related Emergency Department visits increased in the USA by $90 \%$, from 35,581 to 67,497 attendances [93]. A recent US National Poison Data retrospective analysis identified all cases of single-substance SGA exposures coded as 'intentional abuse' [94] during a 10-year period (2003-2013), quetiapine being the most represented molecule, followed by risperidone and olanzapine. Prison inmates and opioid addicts seem to represent the most at-risk populations $[24,75,76,95-97]$. Quetiapine psychotropic effects [86,87] are associated with both increased levels of DA in the nucleus accumbens (NAc) area [89,98-100] and D2 receptor blockage. As some pharmacodynamic mechanisms are shared by other non-misused SGAs [101-104], other factors $[105,106]$ or pharmacological effects explaining the molecule misuse potential may include norquetiapine-related norepinephrine reuptake blockade [75], 5-HT7 antagonist properties and sigma receptor activation $[107,108]$. Quetiapine pharmacokinetics, mediated by the cytochrome CYP3A4, may play a part, as well, in facilitating its misuse [109]. Its XR formulation may be less frequently abused, due to the delayed (by approximately $3 \mathrm{~h}$ ) and blunted (by approximately 67\%) serum peak [88]; the tablet coating may also make snorting of the crushed tablets quite problematic [89].

Another SGA, olanzapine, is normally prescribed at a dosage of 5-20 mg oral daily in order to treat schizophrenia, bipolar disorder and resistant depression. Whilst being widely prescribed, it has been anecdotally reported, at dosages up to $50 \mathrm{mg}$, as the 'ideal trip terminator/modulator' after a psychedelic drug binge [110]. According to discussion forums/specialised websites [111], olanzapine is also being used to treat unwanted 'comedown' symptoms from drug/alcohol intake [112,113]. Consistent with this, clients on methadone maintenance treatment attending the National Drug Treatment Centre (NDTC) in Dublin reported levels of non-medical use of olanzapine, with dosages of up to $100 \mathrm{mg} /$ day, in order to manage anxiety and improve sleep, and in a minority of cases, to 'get stoned' [114]. Olanzapine activity involves GABA-A receptors [115], hence the 
associated sedation, the rewarding glutamatergic stimulation of the ventral tegmental area DAergic neurons [116], the 5HT2C and histamine/H1 antagonist properties and the potent inhibiting action on the muscarinic M1 receptors [115,116]. In comparing quetiapine with olanzapine through the UK Prescription Cost Analysis and the Drug Analysis Profiles of the Yellow Card Scheme, quetiapine was shown to be slightly less frequently prescribed but associated with a smaller total number of general reports, and hence, a comparatively higher number of abuse/dependence/withdrawal ADR reports $[117,118]$. In line with this, the OPPIDUM French addictovigilance network highlighted the emerging misuse of prescription molecules, and this included quetiapine as well [119]. Information from the previous 10 years from the EMA EV database relating to quetiapine and olanzapine misuse/abuse/dependence/withdrawal-related ADR reports [8] shows a higher misuse risk for quetiapine in comparison with olanzapine for the selected ADR reports. Indeed, quetiapine XR formulation was represented in only a smalll proportion of misuse cases, with both nasal and parenteral administration having been identified. Of particular interest was, in comparison with olanzapine, a higher risk of discontinuation/withdrawal syndrome following the abrupt cessation of quetiapine $[75,113,120]$. Finally, consistent with previous data $[75,82-85,90,121-123]$, the quetiapine- and olanzapine-related fatalities reported on the EMA EV database were typically the result of a polydrug intake, which included opiates/opioids, antidepressants, and over-the-counter drugs $[124,125]$.

\subsection{Image-And Performance-Enhancing Drugs (IPEDs)}

Over the last few decades, a range of prescribed and non-prescribed enhancement drugs have increasingly been self-administered [72] in order to improve the ageing process, and sexual performances, and to reduce hair loss, fatigue and other physiological conditions which are, at times, considered pathological in a society that strongly emphasises the importance of physical appearance [126]. Prescribed image- and performance-enhancing drugs (IPEDs) include anabolic-androgenic steroids (AAS), human growth hormone (hGH), steroid hormones (e.g., androstenedione), insulin, erythropoietin, diuretics, but also, $\beta-2$ agonists (e.g., clenbuterol and salbutamol) [127]. Their misuse is typically carried out within a polypharmacy context [128] with alcohol, cannabis/cannabinoids, cocaine, amphetamines/methamphetamines being ingested as ancillary drugs. Moreover, the recent reporting of IPED injecting practices are a reason for concern [129]; these mostly involve anabolic androgenic steroids, non-steroidal anabolic hormones (e.g., hGH and insulin), tanning peptides, cosmetic injectables such as botox and dermal fillers, etc. [130-132]. Among non-steroidal anabolic hormones, insulin seems to be misused for performance-enhancement purposes through several administration routes (intravenous, intramuscular and subcutaneous); indeed, insulin may help in achieving a decrease in fat deposition, an increase in muscle mass and positive mood changes, although serious hypoglycaemic episodes and other medical sequelae can occur as well $[133,134]$. Within the IPED group, anti-asthmatic beta-2 agonists have recently emerged as having potential for misuse, e.g., salbutamol for its performance-enhancing effects and clenbuterol for its hypertrophic and lipolytic effects. They are both included in the list of prohibited substances released by the World Anti-Doping Agency (WADA) [135], with salbutamol being allowed only as a component in the treatment regimen for athletes with asthma. Clenbuterol, even if different from anabolic steroids, has been also prohibited as an anabolic agent since 2006. In parallel with this, the Food and Drug Administration (FDA) banned the use of clenbuterol in food animals in 1991 and the European Union (EU) followed suit in 1996 [136]. Beta-2 agonists are synthetic molecules with sympathomimetic activity, prescribed as bronchodilators for the treatment of asthma. Clenbuterol is licensed for human use only in a few countries (Austria, Germany, Italy, Spain and Mexico), but not in the UK or the USA [137]. Clenbuterol, as a 'size zero pill', is popular and widely available on the web, being considered an ergo/thermogenic drug and hence, an anabolic burner [138], similar to caffeine, ephedrine, and thyroid hormones. Clenbuterol-associated lypolisis can occur via both $\beta-2$ adrenergic agonism and its specific action on the adipocytes' $\beta-3$ adrenergic receptors, which further facilitates lipolysis and weight loss [139-141]. While anti-asthmatic clenbuterol 
dosage ranges between 20 and 40mcg daily, the typical 'fat burning' dose is in the 120-160 mcg daily range; dosage starts at $40 \mathrm{mcg}$ daily, gradually increases, and then remains at the highest dosage for a duration of 2-4 weeks [142]. In parallel with this, recent years have seen an increase in clenbuterol exposure reported to poison control centres [143], with the molecule being used either as a dietary supplement [144] or as an adulterant in illicit drugs, such as cocaine [145]. Its adverse effects are dose-dependent and may include dysrhythmias and myocardial injury, headache, abdominal pain, nausea, and rhabdomyolysis [136,146-148]. Reports relating to salbutamol misuse have been less frequently mentioned [149-151]. Similar to clenbuterol, salbutamol's adverse effects are dose-related and may include tremor, restlessness, anxiety/agitation, tachycardia, atrial fibrillation, and myocardial ischaemia, especially in cases of overdosage, chronic use, or intravenous injection [152]. With respect to salbutamol, clenbuterol's higher levels of abuse potential could be associated with its pharmacological characteristics [143], such as its prolonged elimination half-life ( $35 \mathrm{~h})$ and its higher lipophilicity, which can be associated with a fast transition through the blood-brain barrier. Consistent with this, salbutamol has been described as significantly less potent on a reinforcement schedule than clenbuterol [149,152-154]. Clenbuterol abuse-related fatalities have consistently been reported in the literature [136,140,147,155], whilst salbutamol is considered safer [156]. In this regard, Milano et al. [10] studied the 2006-2016 EMA clenbuterol- and salbutamol-related, misuse/abuse/dependence/withdrawal/overdose/off-label spontaneous reports. They found that clenbuterol, in comparison with salbutamol, had higher levels of misuse/abuse. These clenbuterol-related data were most typically from males and were associated with the intake of steroids [10], hence confirming previous reports [157,158].

\subsection{Over-The-Counter (OTC) Medicines_Loperamide}

Currently, over-the-counter (OTC) abuse ('pharming') is an internationally recognised problem, and the recent emergence of new forms, including online, of medicine supply, is alarming clinicians and health authorities nationwide. The EU introduced a strong legal framework for the licensing, manufacturing and distribution of medicines [159], but no measures have been taken so far for the distribution of OTC drugs, and it is hence, difficult to quantify their actual misuse and abuse [159-168]. Over previous years, the OTC antidiarrhoeal medicine loperamide has increasingly been reported as being diverted and used to achieve recreational effects [159-162]. Loperamide acts as a potent mu-opioid receptor agonist, albeit with predominantly peripheral activity on the myenteric plexus, hence primarily increasing the intestinal transit time by decreasing propulsive activity. Secondary peripheral effects are seen at $\mathrm{K}$-opioid and $\delta$-opioid receptors as well $[169,170]$. Loperamide was initially placed by the US FDA in Schedule V of the Controlled Substance Act but then, after having assessed its safety profile with the conclusion of low levels of physical dependence risk, in 1988, it was made available for OTC use. In the $2-16 \mathrm{mg}$ daily dosage, loperamide is considered safe and devoid of misuse abuse potential because of its rapid metabolism and poor blood-brain barrier (BBB) penetration. In doses of 50-300 $\mathrm{mg}$, however, loperamide ingestion has been associated with euphoria, central nervous system depression [171-174] and even death [175]. Its diversion potential may be associated with its use as a relief from opioid withdrawal [176]. Anecdotally described as the 'poor's' methadone' [177], detailed loperamide dosage titration regimens are being reported online [20]. Related misuse case series [178] have reported both extremely high daily intakes (up to $1200 \mathrm{mg}$ ), and associated cardiotoxicity issues, such as QTc prolongation and torsades de pointes, QRS prolongation, ventricular dysrhythmias [179-182], syncope, and cardiac arrest [12,179,183,184]. The cardiotoxicity mechanism of loperamide is not clearly understood, although it may be due to potent inhibition of cardiac ion channels which is, in turn, associated with delayed repolarisation and QT prolongation [185-187]. Consequently, the FDA [175] has recently warned clinicians and users about the combination of loperamide with other drugs or herbal products that are known to prolong the QT interval, including Class 1A (e.g., quinidine, procainamide) or Class III drugs (e.g., amiodarone, sotalol) antiarrhythmics, antipsychotics (e.g., chlorpromazine, haloperidol, thioridazine, ziprasidone), antibiotics (e.g., moxifloxacin), and methadone. Loperamide ingestion has also been 
reported in association with P-glycoprotein (P-gp) substrates (e.g., quetiapine, cetirizine, oxycodone) or inhibitors (e.g., fluoxetine, citalopram, sertraline, omeprazole, quinine, quinidine, propranolol, ritonavir). These associations are associated with an increase in the low bioavailability of loperamide, normally being $<2 \%$; plasmatic concentration; levels of euphoric effects; the capacity of possible contrasting opioid withdrawal symptoms [186-189]; and toxicity effects [175]. Concurrent use of loperamide with CYP3A4 inhibitors (e.g., itraconazole, grapefruit juice, omeprazole, tonic water and cimetidine) or CYP2C8 inhibitors (e.g., gemfibrozil) can increase its plasma levels as well, with recurrent ventricular tachycardia having been reported in a patient who was taking large recreational doses of both loperamide and the CYP3A4 inhibitor, famotidine [190]. Treatment of loperamide intoxication involves the use of naloxone, which may not be able to directly reverse loperamide cardiotoxic effects [191,192].

\section{Discussion}

The ever-increasing number of NPS emerging worldwide and the parallel changes in drug scenarios represent a challenge for psychiatric, public health and drug-control policies [193]. In line with this, the current systematic review has focused on a different range of prescribed medications which are indeed being used as NPS [1]. Within both online drug forum communities and social networks, there are some educated/informed users (the 'psychonauts') [194] who typically 'test' a range of psychotropics, including prescribed drugs, to achieve specific mindsets and eventually, share this information with peers [193]. However, in parallel with recently increased levels of access to the web, a large number of vulnerable subjects, including both children/adolescents and psychiatric patients, have been exposed to a range of 'pro-drug' information, and this is a reason for concern [193]. Although a number of online 'rogue' pharmacies have been shut down, this typically prompts the sellers to move to servers in overseas countries, leading to a growing black market [195].

It is intriguing that, for the range of prescription molecules discussed, including the fairly recently introduced gabapentinoids, pre-marketing processes were not been able to appropriately identify their abuse/misuse potential. However, similar to what happened with benzodiazepines and z-hypnotics, this potential has finally emerged over time. Present data seem to suggest that abuse liability-focused, pre-marketing laboratory testing may need to consider interaction studies with alcohol and/or other drugs [194,196]. Furthermore, post-marketing surveillance for substance abuse [197] should routinely be carried out to assess the abuse potential of newly released drugs, especially those with activity on the central nervous system (CNS) [198]. Indeed, lack of information on the abuse/misuse potential of a new medicine's interaction with the CNS does not mean that a specific medicine does not actually produce these effects. Furthermore, in order to look at how medicines are actually used in real life, modern pharmacovigilance should identify a range of technical tools and approaches to go beyond spontaneous reporting systems. Physicians should be vigilant when prescribing drugs with an abuse/misuse/diversion potential and carefully evaluate the possibility for some clients (inmates; people with a personal history of misuse or abuse) to be more vulnerable to these misuse activities. Finally, while a continuum of related professional training is needed, it may be important to consider a strategy to increase clients' access to treatment services, possibly through enhanced links between community pharmacists, who are the first professionals to identify a repeat supply issue, and prescribers/clinicians [198].

Author Contributions: F.S. devised the paper, the main conceptual ideas and the proof outline. He contributed to the analysis of the results and the revision of the paper. S.C. performed the systematic literature review and drafted the initial version of the manuscript. J.M.C. and A.G. contributed to the interpretation of related data.

Acknowledgments: No sources of funding for the study are disclosed.

Conflicts of Interest: F.S. is the guest editor of this special issue; an Advisory Council on the Misuse Drugs (ACMD) member, UK; and an EMA Advisory board (psychiatry) member. The authors have no other relevant affiliations or financial involvement with any organization or entity with a financial interest in or financial conflict with the subject matter or materials discussed in the manuscript. 


\section{References}

1. Schifano, F.; Orsolini, L.; Papanti, D.; Corkery, J.M. Novel psychoactive substances of interest for psychiatry. World Psychiatry 2015, 14, 15-26. [CrossRef] [PubMed]

2. United Nations Office for Drugs and Crime (UNODC). Early Warning Advisory on New Psychoactive Substances. Available online: https:/ / www.unodc.org/LSS/Page/NPS (accessed on 20 January 2018).

3. European Monitoring Centre for Drugs and Drug Abuse (EMCDDA). European Drug Report. Trends and Developments; EMCDDA: Lisbon, Portugal, 2017. Available online: http://www.emcdda.europa.eu/system/ files/publications / 4541/TDAT17001ENN.pdf (accessed on 2 March 2018).

4. Zawilska, J.B.; Andrzejczak, D. Next generation of novel psychoactive substances on the horizon-A complex problem to face. Drug Alcohol Depend. 2015, 157, 1-17. [CrossRef] [PubMed]

5. Van Hout, M.C.; Hearne, E. New psychoactive substances (NPS) on crypto market fora: An exploratory study of characteristics of forum activity between NPS buyers and vendors. Int. J. Drug Policy 2017, 40, 102-110. [CrossRef] [PubMed]

6. Soussan, C.; Andersson, M.; Kjellgren, A. The diverse reasons for using Novel Psychoactive Substances-A qualitative study of the users' own perspectives. Int. J. Drug Policy 2018, 52, 71-78. [CrossRef] [PubMed]

7. Chiappini, S.; Schifano, F. A decade of gabapentinoid misuse: An analysis of the European Medicines Agency's 'suspected adverse drug reactions' database. Assessment of gabapentinoid misuse/dependence as reported to the EMA. CNS Drugs 2016, 30,1-8. [CrossRef] [PubMed]

8. Chiappini, S.; Schifano, F. Is there a potential of misuse for quetiapine? Literature review and analysis of the European Medicines Agency/EMA Adverse Drug Reactions' database. J. Clin. Psychopharmacol. 2018, 38, 72-79. [CrossRef] [PubMed]

9. Carvalho, A.F.; Sharma, M.S.; Brunoni, A.R.; Vieta, E.; Fava, G.A. The safety, tolerability and risks associated with the use of newer generation antidepressant drugs: A critical review of the literature. Psychother. Psychosom. 2016, 85, 270-288. [CrossRef] [PubMed]

10. Milano, G.; Chiappini, S.; Mattioli, F.; Martelli, A.; Schifano, F. $\beta-2$ agonists as misusing Drugs? Assessment of both Clenbuterol- and Salbutamol-related European Medicines Agency (EMA) Pharmacovigilance Database Reports. Basic Clin. Pharmacol. Toxicol. 2018, 2. [CrossRef]

11. Sheridan, D.C.; Hendrickson, R.G.; Beauchamp, G.; Laurie, A.; Fu, R.; Horowitz, B.Z. Adolescent Intentional Abuse Ingestions: Overall 10-Year Trends and Regional Variation. Pediatr. Emerg. Care 2016. [CrossRef] [PubMed]

12. Lasoff, D.R.; Koh, C.H.; Corbett, B.; Minns, A.B.; Cantrell, F.L. Loperamide Trends in Abuse and Misuse Over 13 Years: 2002-2015. Pharmacotherapy 2017, 37, 249-253. [CrossRef] [PubMed]

13. European Medicines Agency (EMA). Pharmacovigilance. Available online: http:/ /www.ema.europa.eu/ ema/index.jsp?curl=pages $/$ regulation /general/general_content_000258.jsp (accessed on 20 January 2017).

14. European Medicines Agency (EMA). EudraVigilance. Available online: http://www.ema.europa.eu/ema/ index.jsp?curl=pages/regulation/general/general_content_000679.jsp (accessed on 3 March 2018).

15. Prisma. Transparent Reporting of Systematic Reviews and Meta-Analyses. Available online: http://www. prisma-statement.org/ (accessed on 21 December 2017).

16. Schifano, F. Misuse and Abuse of Pregabalin and Gabapentin: Cause for Concern? CNS Drugs 2014, $28,491$. [CrossRef] [PubMed]

17. Evoy, K.E.; Morrison, M.D.; Saklad, S.R. Abuse and Misuse of Pregabalin and Gabapentin. Drugs 2017, 77, 403-426. [CrossRef] [PubMed]

18. Schjerning, O.; Rosenzweig, M.; Pottegård, A.; Damkier, P.; Nielsen, J. Abuse Potential of Pregabalin: A Systematic Review. CNS Drugs 2016, 30, 9-25. [CrossRef] [PubMed]

19. Schjerning, O.; Pottegård, A.; Damkier, P.; Rosenzweig, M.; Nielsen, J. Use of Pregabalin-A Nationwide Pharmacoepidemiological Drug Utilization Study with Focus on Abuse Potential. Pharmacopsychiatry 2016, 49, 155-161. [CrossRef] [PubMed]

20. Erowid. Experiences. Available online: https:/ / erowid.org/experiences/ (accessed on 16 January 2018).

21. Drug Enforcement Administration. Schedules of Controlled Substances: Placement of Pregabalin into Schedule V. Available online: https://www.deadiversion.usdoj.gov/fed_regs/rules/2005/fr0728.htm (accessed on 16 January 2018). 
22. Bonnet, U.; Scherbaum, N. How addictive are gabapentin and pregabalin? A systematic review. Eur. Neuropsychopharmacol. 2017, 27, 1185-1215. [CrossRef] [PubMed]

23. Daly, C.; Griffin, E.; Ashcroft, D.M.; Webb, R.T.; Perry, I.J.; Arensman, E. Intentional Drug Overdose Involving Pregabalin and Gabapentin: Findings from the National Self-Harm Registry Ireland, 2007-2015. Clin. Drug Investig. 2017, 20. [CrossRef] [PubMed]

24. Reeves, R.R.; Ladner, M.E. Potentiation of the effect of buprenorphine/naloxone with gabapentin or quetiapine. Am. J. Psychiatry 2014, 171, 691. [CrossRef] [PubMed]

25. Greater use of gabapentinoids in intentional drug overdose. Available online: https://doi.org/10.1007/ s40278-018-40617-3 (accessed on 21 April 2018).

26. OECD Indicators. Health at a Glance. 2015. Available online: http://www.keepeek.com/Digital-AssetManagement/oecd/social-issues-migration-health/health-at-a-glance-2015_health_glance-2015-en\# page187 (accessed on 20 January 2018).

27. Kantor, E.D.; Rehm, C.D.; Haas, J.S.; Chan, A.T.; Giovannucci, E.L. Trends in prescription drug use among adults in the US from 1999-2012. JAMA 2015, 314, 1818-1831. [CrossRef] [PubMed]

28. Anderson, L.S.; Bell, H.G.; Gilbert, M.; Davidson, J.E.; Winter, C.; Barratt, M.J.; Win, B.; Painter, J.L.; Menone, C.; Sayegh, J.; et al. Using Social Listening Data to Monitor Misuse and Nonmedical Use of Bupropion: A Content Analysis. JMIR Public Health Surveill. 2017, 3, e6. [CrossRef] [PubMed]

29. Evans, E.A.; Sullivan, M.A. Abuse and misuse of antidepressants. Subst. Abuse Rehabil. 2014, 5, 107-120. [CrossRef] [PubMed]

30. McCormick, J. Recreational bupropion abuse in a teenager. Br. J. Clin. Pharmacol. 2002, 53, 211-214. [CrossRef]

31. Welsh, C.J.; Doyon, S. Seizure-induced by insufflation of bupropion. N. Engl. J. Med. 2002, 347, 951. [CrossRef] [PubMed]

32. Glaxo Smith and Kline (GSK). 201235 Clinical Study Result Summary. PRJ2215: Assessment of Buproprion Misuse/Abuse 2004-2011. Updated August 2016. Available online: https:/ / www.gsk-clinicalstudyregister. com/files2/201235-Clinical-Study-Result-Summary.pdf (accessed on 20 October 2017).

33. Reeves, R.R.; Ladner, M.E. Additional evidence of the abuse potential of bupropion. J. Clin. Psychopharmacol. 2013, 33, 584-585. [CrossRef] [PubMed]

34. Baribeau, D.; Araki, K.F. Intravenous bupropion: A previously undocumented method of abuse of a commonly prescribed antidepressant agent. J. Addict. Med. 2013, 7, 216-217. [CrossRef] [PubMed]

35. Stahl, S.M.; Pradko, J.F.; Haight, B.R.; Modell, J.G.; Rockett, C.B.; Learned-Coughlin, S. A Review of the Neuropharmacology of Bupropion, a Dual Norepinephrine and DA Reuptake Inhibitor. J. Clin. Psychiatry 2004, 6, 159-166. [CrossRef]

36. Guzman, F. The Psychopharmacology of Bupropion: An Illustrated Overview. Available online: http: //psychopharmacologyinstitute.com/antidepressants/bupropion-psychopharmacology/ (accessed on 7 October 2017).

37. Prosser, J.M.; Nelson, L.S. The toxicology of bath salts: A review of synthetic cathinones. J. Med. Toxicol. 2012, 8, 33-42. [CrossRef] [PubMed]

38. Vento, A.E.; Schifano, F.; Gentili, F.; Pompei, F.; Corkery, J.M.; Kotzalidis, G.D.; Girardi, P. Bupropion perceived as a stimulant by two patients with a previous history of cocaine misuse. Ann. Super Sanita 2013, 49, 402-405. [CrossRef]

39. Rettew, D.C.; Hudziak, J.J. Bupropion. In Essentials of Clinical Psychopharmacology, 2nd ed.; Schatzberg, A.F., Nemeroff, C.B., Eds.; American Psychiatric Publishing Inc.: Arlington, VA, USA, 2001; ISBN 1585624195.

40. Stall, N.; Godwin, J.; Juurlink, D. Bupropion abuse and overdose. CMAJ 2014, 186, 1015. [CrossRef] [PubMed]

41. Stassinos, G.L.; Klein-Schwartz, W. Bupropion "Abuse” Reported to US Poison Centers. J. Addict. Med. 2016, 10, 357-362. [CrossRef] [PubMed]

42. Toxnet, Toxicology Data Network. Bupropion; National Library of Medicine HSDB Database. 2015. Available online: https: / toxnet.nlm.nih.gov/cgi-bin/sis/search/a?dbs+hsdb:@term+@DOCNO+6988 (accessed on 19 October 2017).

43. Hill, S.; Sikand, H.; Lee, J. Letter to the editor. A case report of seizure induced by bupropion nasal insufflation. J. Clin. Psychiatry 2007, 9, 67-69.

44. Yoon, G.; Westermeyer, J. Intranasal bupropion abuse case report. Am. J. Addict. 2013, 22, 180. [CrossRef] [PubMed] 
45. Hilliard, W.T.; Barloon, L.; Farley, P.; Penn, J.V.; Koranek, A. Bupropion diversion and misuse in the correctional facility. J. Correct. Health Care 2013, 19, 211-217. [CrossRef] [PubMed]

46. Phillips, D. Wellbutrin: Misuse and abuse by incarcerated individuals. J. Addict. Nurs. 2012, $23,65-69$. [CrossRef] [PubMed]

47. Laird, G.; Narayan, P. Formulary Controls: Abuse of Psychotropics, and Dispensary Costs in the Incarceration Environment. Available online: http:/ / www.fmhac.net/Assets/Documents/2009/Presentations/Laird\% 20Formulary\%20Controls.pdf (accessed on 6 October 2017).

48. European Medicines Agency (EMA). Venlafaxine. 2007. Available online: http://www.ema.europa.eu/ ema/index.jsp?curl=pages/medicines/human/referrals /Efexor/human_referral_000020.jsp (accessed on 20 December 2017).

49. Harvey, A.T.; Rudolph, R.L.; Preskorn, S.H. Evidence of the dual mechanisms of action of venlafaxine. Arch. Gen. Psychiatry 2000, 57, 503-509. [CrossRef] [PubMed]

50. Weikop, P.; Kehr, J.; Scheel-Krüger, J. The role of alpha1- and alpha2-adrenoreceptors on venlafaxine-induced elevation of extracellular serotonin, noradrenaline and DA levels in the rat prefrontal cortex and hippocampus. J. Psychopharmacol. 2004, 18, 395-403. [CrossRef] [PubMed]

51. Maj, J.; Rogoz, Z. Pharmacological effects of venlafaxine, a new antidepressant, given repeatedly, on the alpha 1-adrenergic, DA and serotonin systems. J. Neural Transm. 1999, 106, 197-211. [CrossRef] [PubMed]

52. Sabljić, V.; Ružić, K.; Rakun, R. Venlafaxine withdrawal syndrome. Psychiatr. Danub. 2011, 23, 117-119. [PubMed]

53. Fava, M.; Mulroy, R.; Alpert, J.; Nierenberg, A.; Rosenbaum, J. Emergence of adverse events following discontinuation of treatment with extended-release venlafaxine. Am. J. Psychiatry 1997, 12, 1760-1762. [CrossRef] [PubMed]

54. Stahl, S.M.; Grady, M.M.; Moret, C.; Briley, M. SNRIs: Their pharmacology, clinical efficacy, and tolerability in comparison with other classes of antidepressants. CNS Spectr. 2005, 10, 732-747. [CrossRef] [PubMed]

55. Sir, A.; D'Souza, R.F.; Uguz, S.; George, T.; Vahip, S.; Hopwood, M.; Martin, A.J.; Lam, W.; Burt, T. Randomized Trial of Sertraline Versus Venlafaxine XR in Major Depression: Efficacy and Discontinuation Symptoms. J. Clin. Psychiatry 2005, 66, 1312-1320. [CrossRef] [PubMed]

56. Taylor, D.; Stewart, S.; Connolly, A. Antidepressant withdrawal symptoms-telephone calls to a national medication helpline. J. Affect. Disord. 2006, 95, 129-133. [CrossRef] [PubMed]

57. Llorca, P.M.; Fernandez, J.L. Escitalopram in the treatment of major depressive disorder: Clinical efficacy, tolerability and cost-effectiveness vs. venlafaxine extended-release formulation. Int. J. Clin. Pract. 2007, 61, 702-710. [CrossRef] [PubMed]

58. Kotzalidis, G.D.; de Pisa, E.; Patrizi, B.; Savoja, V.; Ruberto, G.; Girardi, P. Similar discontinuation symptoms for withdrawal from medium-dose paroxetine and venlafaxine. J. Psychopharmacol. 2008, 22, 581-584. [CrossRef] [PubMed]

59. Koga, M.; Kodaka, F.; Miyata, H.; Nakayama, K. Symptoms of delusion: The effects of discontinuation of low-dose venlafaxine. Acta Psychiatr. Scand. 2008, 120, 329-331. [CrossRef] [PubMed]

60. Holland, J.; Brown, R. Neonatal venlafaxine discontinuation syndrome: A mini-review. Eur. J. Paediatr. Neurol. 2017, 21, 264-268. [CrossRef] [PubMed]

61. Cutler, N. Severe Venlafaxine Withdrawal Successfully Treated With a Short Course of Duloxetine. Prim. Care Companion CNS Disord. 2017, 19. [CrossRef] [PubMed]

62. Groot, P.C. Consensus group Tapering. [Tapering strips for paroxetine and venlafaxine]. Tijdschr. Psychiatr. 2013, 55, 789-794. [PubMed]

63. Francesconi, G.; Orsolini, L.; Papanti, D.; Corkery, J.M.; Schifano, F. Venlafaxine as the 'baby ecstasy'? Literature overview and analysis of web-based misusers' experiences. Hum. Psychopharmacol. 2015, 30, 255-261. [CrossRef] [PubMed]

64. Sattar, S.P.; Grant, K.M.; Bhatia, S.C. A case of venlafaxine abuse. N. Engl. J. Med. 2003, 348, 764-765. [CrossRef] [PubMed]

65. Venlafaxine overdose. Available online: https://doi.org/10.1007/s40278-018-40604-4 (accessed on 21 April 2018).

66. Baker, D.R.; Barron, L.; Kasprzyk-Hordern, B. Illicit and pharmaceutical drug consumption estimated via wastewater analysis. Part A: Chemical analysis and drug use estimates. Sci. Total Environ. 2014, 487, 629-641. [CrossRef] [PubMed] 
67. Fountain, J.S.; Slaughter, R.J. TOXINZ, the New Zealand Internet poisons information database: The first decade. Emerg. Med. Australas. 2016, 28, 335-340. [CrossRef] [PubMed]

68. Schifano, F.; Chiappini, S. Is there a potential of misuse for venlafaxine and bupropion? Front. Neuropharmacol. 2018, 9. [CrossRef] [PubMed]

69. Health and Social Care Information Centre (HSCIC). Prescriptions Dispensed in the Community. England 2004-2014. Available online: http:/ / content.digital.nhs.uk/catalogue/PUB17644/pres-disp-com-eng-200414-rep.pdf (accessed on 20 February 2017).

70. Bogart, G.T.; Ott, C.A. Abuse of second-generation antipsychotics: What prescribers need to know. Curr. Psychiatry 2011, 10, 77-79. [CrossRef]

71. Sarker, A.; O'Connor, K.; Ginn, R.; Scotch, M.; Smith, K.; Malone, D.; Gonzalez, G. Social Media Mining for Toxicovigilance: Automatic Monitoring of Prescription Medication Abuse from Twitter. Drug Saf. 2016, 39, 231-240. [CrossRef] [PubMed]

72. Advisory Council on the Misuse Drugs (ACMD). ACMD Report on Diversion and Illicit Supply of Medicines. 2016. Available online: https://www.gov.uk/government/uploads/system/uploads/attachment_data/ file/580296/Meds_report-_final_report_15_December_LU_2_.pdf (accessed on 26 February 2018).

73. Food and Drug Administration (FDA). Seroquel Prescribing Information. 2010. Available online: http:/ / www. accessdata.fda.gov/drugsatfda_docs/label/2011/020639s049s054lbl.pdf (accessed on 20 February 2017).

74. Terán, A.; Majadas, S.; Galan, J. Quetiapine in the treatment of sleep disturbances associated with addictive conditions: A retrospective study. Subst. Use Misuse 2008, 43, 2169-2171. [CrossRef]

75. Srivastava, A.; Patil, V.; Da Silva Pereira, Y. A Case Series of Quetiapine Addiction/Dependence. Ger. J. Psychiatr. 2013, 16, 152-155.

76. Kim, S.; Lee, G.; Kim, E.; Jung, H.; Chang, J. Quetiapine Misuse and Abuse: Is it an Atypical Paradigm of Drug-Seeking Behavior? J. Res. Pharm. Pract. 2017, 6, 12-15. [CrossRef] [PubMed]

77. Di Chiara, G.; Imperato, A. Drugs abused by humans preferentially increase synaptic DA concentrations in the mesolimbic system of freely moving rats. Proc. Natl. Acad. Sci. USA 1988, 85, 5274-5278. [CrossRef] [PubMed]

78. Waters, B.M.; Joshi, K.G. Intravenous Quetiapine-Cocaine Use (“Q-Ball”). Am. J. Psychiatry 2007, 164, $173-174$. [CrossRef] [PubMed]

79. Pierre, J.M.; Shnayder, I.; Wirshing, D.A.; Wirshing, W.C. Intranasal quetiapine abuse. Am. J. Psychiatry 2004, 61, 1718. [CrossRef] [PubMed]

80. George, M.; Haasz, M.; Coronado, A.; Salhanick, S.; Korbel, L.; Kitzmiller, J.P. Acute dyskinesia, myoclonus, and akathisia in an adolescent male abusing quetiapine via nasal insufflation: A case study. BMC Pediatr. 2013, 13, 187. [CrossRef] [PubMed]

81. Morin, A.K. Possible intranasal quetiapine misuse. Am. J. Health Syst. Pharm. 2007, 64, 723-725. [CrossRef] [PubMed]

82. Fischer, B.A.; Boggs, D.L. The role of antihistaminic effects in the misuse of quetiapine: A case report and review of the literature. Neurosci. Biobehav. Rev. 2010, 34, 555-558. [CrossRef] [PubMed]

83. Reeves, R.R.; Brister, J.C. Additional evidence of the abuse potential of quetiapine. South. Med. J. 2007, 100, 834-836. [CrossRef] [PubMed]

84. Paparrigopoulos, T.; Karaiskos, D.; Liappas, J. Quetiapine: Another drug with potential for misuse? A case report. J. Clin. Psychiatry 2008, 69, 162-163. [CrossRef] [PubMed]

85. Chen, C.Y.; Shiah, I.S.; Lee, W.K.; Kuo, S.C.; Huang, C.C.; Wang, T.Y. Dependence on quetiapine in combination with zolpidem and clonazepam in bipolar depression. Psychiatry Clin. Neurosci. 2009, 63, 427-428. [CrossRef] [PubMed]

86. Hussain, M.Z.; Waheed, W.; Hussain, S. Intravenous quetiapine abuse. Am. J. Psychiatry 2005, 162, $1755-1756$. [CrossRef] [PubMed]

87. Sansone, R.A.; Sansone, L.A. Is Seroquel developing an illicit reputation for misuse/abuse? Psychiatry 2010, 7, 13-16.

88. Murphy, D.; Bailey, K.; Stone, M.; Wirshing, W.C. Addictive potential of quetiapine. Am. J. Psychiatry 2008, 165, 167. [CrossRef] [PubMed]

89. Peyrière, H.; Diot, C.; Eiden, C.; Petit, P. Réseau de centres de d'Addictovigilance. Abuse Liability of Quetiapine (Xeroquel®): Analysis of the literature. Fundam. Clin. Pharmacol. 2015, 29, 27-28. [CrossRef] 
90. Pilgrim, J.L.; Drummer, O.H. The toxicology and comorbidities of fatal cases involving quetiapine. Forensic Sci. Med. Pathol. 2013, 9, 170-176. [CrossRef] [PubMed]

91. Haller, E.; Bogunovic, O.; Miller, M. Atypical antipsychotics new drugs of abuse. In Proceedings of the American Academy of Addiction Psychiatry (AAAP) 24th Annual Meeting \& Symposium, Scottsdale, AZ, USA, 7 December 2013. Abstract 16.

92. Heilbronn, C.; Lloyd, B.; McElwee, P.; Eade, A.; Lubman, D.E. Trends in quetiapine use and non-fatal quetiapine-related ambulance attendances. Drug Alcohol Rev. 2013, 32, 405-411. [CrossRef] [PubMed]

93. Mattson, M.E.; Albright, V.; Yoon, J.; Council, C.L. Emergency Department Visits Involving Misuse and Abuse of the Antipsychotic Quetiapine: Results from the Drug Abuse Warning Network (DAWN). Subst. Abuse 2015, 9, 39-46. [CrossRef] [PubMed]

94. Klein, L.; Bang, S.; Cole, J.B. Intentional Recreational Abuse of Quetiapine Compared to Other Second-generation Antipsychotics. West. J. Emerg. Med. 2017, 18, 243-250. [CrossRef] [PubMed]

95. Pinta, E.R.; Taylor, R.E. Letter to the editor. Quetiapine Addiction? Am. J. Psychiatry 2007, 164, 1. [CrossRef] [PubMed]

96. McLarnon, M.E.; Fulton, H.G.; MacIsaac, C.; Barrett, S.P. Characteristics of quetiapine misuse among clients of a community-based methadone maintenance program. J. Clin. Psychopharmacol. 2012, 32, 721-723. [CrossRef] [PubMed]

97. Malekshahi, T.; Tioleco, N.; Ahmed, N.; Campbell, A.N.; Haller, D. Misuse of atypical antipsychotics in conjunction with alcohol and other drugs of abuse. J. Subst. Abuse Treat. 2015, 48, 8-12. [CrossRef] [PubMed]

98. Cha, H.J.; Lee, H.A.; Ahn, J.I.; Jeon, S.H.; Kim, E.J.; Jeong, H.S. Dependence potential of quetiapine: Behavioral pharmacology in rodents. Biomol. Ther. 2013, 21, 307-312. [CrossRef] [PubMed]

99. Tanda, G.; Valentini, V.; De Luca, M.A.; Perra, V.; Serra, G.P.; Di Chiara, G. A systematic microdialysis study of DA transmission in the accumbens shell/core and prefrontal cortex after acute antipsychotics. Psychopharmacology 2015, 232, 1427-1440. [CrossRef]

100. Brutcher, R.E.; Nader, S.H.; Nader, M.A. Evaluation of the reinforcing effect of Quetiapine, alone and in combination with cocaine, in Rhesus monkeys. J. Pharmacol. Exp. Ther. 2016, 356, 244-250. [CrossRef] [PubMed]

101. Kapur, S.; Seeman, P. Antipsychotic agents differ in how fast they come off the DA D2 receptors. Implications for atypical antipsychotic action. J. Psychiatry Neurosci. 2000, 25, 161-166. [PubMed]

102. Tauscher, J.; Hussain, T.; Agid, O.; Verhoeff, N.P.; Wilson, A.A.; Houle, S.; Remington, G.; Zipursky, L.P.; Kapur, S. Equivalent occupancy of DA D1 and D2 receptors with clozapine: Differentiation from other atypical antipsychotics. Am. J. Psychiatry 2004, 161, 1620-1625. [CrossRef] [PubMed]

103. Kuroki, T.; Nagao, N.; Nakahara, T. Neuropharmacology of second-generation antipsychotic drugs: A validity of the serotonin-DA hypothesis. Prog. Brain Res. 2008, 172, 199-212. [CrossRef] [PubMed]

104. Kapur, S.; Remington, G. Atypical antipsychotics: New directions and new challenges in the treatment of schizophrenia. Ann. Rev. Med. 2001, 52, 503-517. [CrossRef] [PubMed]

105. Montebello, M.E.; Brett, J. Misuse and Associated Harms of Quetiapine and Other Atypical Antipsychotics. Curr. Top. Behav. Neurosci. 2017, 34, 125-139. [CrossRef] [PubMed]

106. Navailles, S.; De Deurwaerdère, P. Presynaptic control of serotonin on striatal DA function. Psychopharmacology 2011, 213, 213-242. [CrossRef] [PubMed]

107. Kotagale, N.R.; Mendhi, S.M.; Aglawe, M.M.; Umekar, M.J.; Taksande, B.G. Evidences for the involvement of sigma receptors in antidepressant-like effect of quetiapine in mice. Eur. J. Pharmacol. 2013, 702, 180-186. [CrossRef] [PubMed]

108. Yasui, Y.; Su, T.P. Potential Molecular Mechanisms on the Role of the Sigma-1 Receptor in the Action of Cocaine and Methamphetamine. J. Drug Alcohol Res. 2016, 5. [CrossRef] [PubMed]

109. Grabowski, K. Quetiapine abuse and dependence: Is pharmacokinetics important? Acta Clin. Belg. 2017, 13, 1. [CrossRef] [PubMed]

110. Dahr, R.; Sidana, A.; Singh, T. Olanzapine Dependence. Ger. J. Psychiatry 2010, 13, 51-53.

111. Valeriani, G.; Corazza, O.; Bersani, F.S.; Melcore, C.; Metastasio, A.; Bersani, G.; Schifano, F. Olanzapine as the ideal "trip terminator"? Analysis of online reports relating to antipsychotics' use and misuse following occurrence of novel psychoactive substance-related psychotic symptoms. Hum. Psychopharmacol. 2015, 30, 249-254. [CrossRef] [PubMed]

112. Reeves, R.R. Abuse of olanzapine by substance abusers. J. Psychoact. Drugs 2007, 39, 297-299. [CrossRef] [PubMed] 
113. Kumsar, N.A.; Erol, A. Olanzapine abuse. Subst. Abuse 2013, 34, 73-74. [CrossRef] [PubMed]

114. James, P.D.; Fida, A.S.; Konovalov, P.; Smyth, B.P. Non-medical use of olanzapine by people on methadone treatment. BJPsych Bull. 2016, 40, 314-317. [CrossRef] [PubMed]

115. Skilbeck, K.J.; O’Reilly, J.N.; Johnston, G.A.; Hinton, T. The effects of antipsychotic drugs on GABAA receptor binding depend on period of drug treatment and binding site examined. Schizophr. Res. 2007, 90, 76-80. [CrossRef] [PubMed]

116. Egerton, A.; Ahmad, R.; Hirani, E.; Grasby, P.M. Modulation of striatal DA release by 5-HT2A and 5-HT2C receptor antagonists: [11C]raclopride PET studies in the rat. Psychopharmacology 2008, 200, 487-496. [CrossRef] [PubMed]

117. National Health Service (NHS) Prescription Cost Analysis (PCA) Data. 2016. Available online: http: / / www.nhsbsa.nhs.uk/PrescriptionServices/3494.aspx (accessed on 11 July 2017).

118. Medicines and Health Regulatory Agency (MHRA). Drug Analysis Profiles. The Yellow Card Scheme. 2016. Available online: Https:/ / yellowcard.mhra.gov.uk/the-yellow-card-scheme/ (accessed on 11 July 2017).

119. Frauger, E.; Pochard, L.; Boucherie, Q.; Chevallier, C.; Daveluy, A.; Gibaja, V.; Caous, A.S.; Eiden, C.; Authier, N.; Le Boisselier, R.; et al. Le Réseau français d'addictovigilance. Surveillance system on drug abuse: Interest of the French national OPPIDUM program of French addictovigilance network. Therapie 2017. [CrossRef] [PubMed]

120. Cerovecki, A.; Musil, R.; Klimke, A.; Seemüller, F.; Haen, E.; Schennach, R.; Kühn, K.U.; Volz, H.P.; Riedel, M. Withdrawal symptoms and rebound syndromes associated with switching and discontinuing atypical antipsychotics: Theoretical background and practical recommendations. CNS Drugs 2013, 27, 545-572. [CrossRef] [PubMed]

121. Parker, D.R.; McIntyre, I.M. Case studies of postmortem quetiapine: Therapeutic or toxic concentrations? J. Anal. Toxicol. 2005, 29, 407-412. [CrossRef] [PubMed]

122. Skov, L.; Johansen, S.S.; Linnet, K. Postmortem Quetiapine Reference Concentrations in Brain and Blood. J. Anal. Toxicol. 2015, 39, 557-561. [CrossRef] [PubMed]

123. Vance, C.; McIntyre, I.M. Postmortem Tissue Concentrations of Olanzapine. J. Anal. Toxicol. 2009, 33, 15-26. [CrossRef] [PubMed]

124. Aspirin/paracetamol/quetiapine overdose. Available online: https://doi.org/10.1007/s40278-018-40658-z (accessed on 21 April 2018).

125. Quetiapine/trazodone overdose. Available online: https://doi.org/10.1007/s40278-018-40528-4 (accessed on 21 April 2018).

126. McVeigh, J.; Evans-Brown, M.; Bellis, M.A. Human enhancement drugs and the pursuit of perfection. Adicciones 2012, 24, 185-190. [CrossRef] [PubMed]

127. Corazza, O.; Bersani, F.S.; Brunoro, R.; Valeriani, G.; Martinotti, G.; Schifano, F. The diffusion of Performance and Image-Enhancing Drugs (IPEDs) on the Internet: The Abuse of the Cognitive Enhancer Piracetam. Subst. Use Misuse 2014, 49, 1849-1856. [CrossRef] [PubMed]

128. Sagoe, D.; McVeigh, J.; Bjørnebekk, A.; Essilfie, M.; Schou Andreassen, C.; Pallesen, S. Polypharmacy among anabolic-androgenic steroid users: A descriptive metasynthesis. Subst. Abuse Treat. Prev. Policy 2015, 10, 12. [CrossRef] [PubMed]

129. Brennan, R.; Wells, J.S.G.; Van Hout, M.C. The injecting use of image and performance-enhancing drugs (IPED) in the general population: A systematic review. Health Soc. Care Community 2017, 25, 1459-1531. [CrossRef] [PubMed]

130. Van Hout, M.C.; Kean, J. An exploratory study of image and performance enhancement drug use in a male British South Asian community. Int. J. Drug Policy 2015, 26, 860-867. [CrossRef] [PubMed]

131. Rowe, R.; Berger, I.; Yaseen, B.; Copeland, J. Risk and blood-borne virus testing among men who inject image and performance enhancing drugs, Sydney, Australia. Drug Alcohol Rev. 2017, 36, 658-666. [CrossRef] [PubMed]

132. Van de Ven, K.; Koenraadt, R. Exploring the relationship between online buyers and sellers of image and performance enhancing drugs (IPEDs): Quality issues, trust and self-regulation. Int. J. Drug Policy 2017, 50, 48-55. [CrossRef] [PubMed]

133. Albertson, T.E.; Chenoweth, J.A.; Colby, D.K.; Sutter, M.E. The Changing Drug Culture: Use and Misuse of Appearance- and Performance-Enhancing Drugs. FP Essent. 2016, 441, 30-43. [PubMed] 
134. Cassidy, E.M.; O'Halloran, D.J.; Barry, S. Insulin as a substance of misuse in a patient with insulin dependent diabetes mellitus. BMJ 1999, 319, 1417-1418. [CrossRef] [PubMed]

135. World Anti-Doping Agency (WADA). The Prohibited List 2017. Available online: https:/ /www.wada-ama. org/sites /default/files/resources / files /2016-09-29_-_wada_prohibited_list_2017_eng_final.pdf (accessed on 24 January 2018).

136. Grimmer, N.M.; Gimbar, R.P.; Bursua, A.; Patel, M. Rhabdomyolysis Secondary to Clenbuterol Use and Exercise. J. Emerg. Med. 2016, 50, e71-e74. [CrossRef] [PubMed]

137. Mottram, D.R.; Chester, N. Drugs in Sports, 6th ed.; Routledge: Abington-on-Thames, UK, 2014; ISBN 9780415715287.

138. Quinley, K.E.; Chen, H.Y.; Yang, H.S.; Lynch, K.L.; Olson, K.R. Clenbuterol causing non-ST-segment elevation myocardial infarction in a teenage female desiring to lose weight: Case and brief literature review. Am. J. Emerg. Med. 2016, 34, 1739. [CrossRef] [PubMed]

139. Al-Majed, A.A.; Khalil, N.Y.; Khbrani, I.; Abdel-Aziz, H.A. Clenbuterol Hydrochloride. Profiles Drug Subst. Excip. Relat. Methodol. 2017, 42, 91-123. [CrossRef] [PubMed]

140. Spiller, H.A.; James, K.J.; Scholzen, S.; Borys, D.J. A descriptive study of adverse events from clenbuterol misuse and abuse for weight loss and bodybuilding. Subst. Abuse 2013, 34, 306-312. [CrossRef] [PubMed]

141. Howard, R. The Size Zero Pill. Available online: http://www.dailymail.co.uk/femail/article-409347/Thesize-zero-pill.html (accessed on 13 November 2017).

142. Steroidal.com. Clenbuterol Dosage. Available online: Https://www.steroidal.com/fat-loss-agents/ clenbuterol/clenbuterol-dosage/ (accessed on 2 November 2017).

143. Brett, J.; Dawson, A.H.; Brown, J.A. Clenbuterol toxicity: A NSW poisons information centre experience. Med. J. Aust. 2014, 200, 219-221. [CrossRef] [PubMed]

144. Van der Bijl, P.; Tutelyan, V.A. Dietary supplements containing prohibited substances. Vopr. Pitan 2013, 82, 6-13. [PubMed]

145. Solimini, R.; Rotolo, M.C.; Pellegrini, M.; Minutillo, A.; Pacifici, R.; Busardò, F.P.; Zaami, S. Adulteration Practices of Psychoactive Illicit Drugs: An Updated Review. Curr. Pharm. Biotechnol. 2017, 18, 524-530. [CrossRef] [PubMed]

146. Barry, A.R.; Graham, M.M. Case report and review of clenbuterol cardiac toxicity. J. Cardiol. Cases 2013, 8, 131-133. [CrossRef]

147. Huckins, D.S.; Lemons, M.F. Myocardial ischemia associated with clenbuterol abuse: Report of two cases. J. Emerg. Med. 2013, 44, 444-449. [CrossRef] [PubMed]

148. Daubert, G.P.; Mabasa, V.H.; Leung, V.W.; Aaron, C. Acute clenbuterol overdose resulting in supraventricular tachycardia and atrial fibrillation. J. Med. Toxicol. 2007, 3, 56-60. [CrossRef] [PubMed]

149. Ferrua, S.; Varbella, F.; Conte, M.R. Acute myocardial infarction due to coronary vasospasm and salbutamol abuse. Heart 2009, 95, 673. [CrossRef] [PubMed]

150. Patanè, S.; Marte, F.; La Rosa, F.C.; La Rocca, R. Atrial fibrillation associated with chocolate intake abuse and chronic salbutamol inhalation abuse. Int. J. Cardiol. 2010, 145, e74-e76. [CrossRef] [PubMed]

151. Boucher, A.; Payen, C.; Garayt, C.; Ibanez, H.; Dieny, A.; Doche, C.; Chuniaud, C.; Descotes, J. Salbutamol misuse or abuse with fatal outcome: A case report. Hum. Exp. Toxicol. 2011, 30, 1869-1871. [CrossRef] [PubMed]

152. O'Donnell, J.M. Effects of clenbuterol and prenalterol on performance during differential reinforcement of low response rate in the rat. J. Pharmacol. Exp. Ther. 1987, 241, 68-75. [PubMed]

153. Edwards, J.G.; Holgate, S.T. Dependency upon salbutamol inhalers. Br. J. Psychiatry 1979, 134, $624-626$. [CrossRef] [PubMed]

154. Morgan, D.J.; Paull, J.D.; Richmond, B.H.; Wilson-Evered, E.; Ziccone, S.P. Pharmacokinetics of intravenous and oral salbutamol and its sulphate conjugate. Br. J. Clin. Pharmacol. 1986, 22, 587-593. [CrossRef] [PubMed]

155. Pope, H.G.; Wood, R.I.; Rogol, A.; Nyberg, F.; Bowers, L.; Bhasin, S. Adverse health consequences of performance-enhancing drugs: An Endocrine Society scientific statement. Endocr. Rev. 2013, 35, 341-375. [CrossRef] [PubMed]

156. Lewis, L.D.; Essex, E.; Volans, G.N.; Cochrane, G.M. A study of self- poisoning with oral salbutamol-laboratory and clinical features. Hum. Exp. Toxicol. 1993, 12, 397-401. [CrossRef] [PubMed]

157. Nicoli, R.; Petrou, M.; Badoud, F.; Dvorak, J.; Saugy, M.; Baume, N. Quantification of clenbuterol at trace level in human urine by ultra-high pressure liquid chromatography-tandem mass spectrometry. J. Chromatogr. A 2013, 1292, 142-150. [CrossRef] [PubMed] 
158. Vaso, M.; Weber, A.; Tscholl, P.M.; Junge, A.; Dvorak, J. Use and abuse of medication during 2014 FIFA World Cup Brazil: A retrospective survey. BMJ Open 2015, 5, E007608. [CrossRef] [PubMed]

159. EMA. Buying Medicine Online. Available online: http:/ /www.ema.europa.eu/ema/index.jsp?curl=pages / regulation/general/general_content_000630.jsp\&mid=WC0b01ac05808fd210 (accessed on 11 November 2017).

160. Miller, H.; Panahi, L.; Tapia, D.; Tran, A.; Bowman, J.D. Loperamide misuse and abuse. J. Am. Pharm. Assoc. 2017, 57, S45-S50. [CrossRef] [PubMed]

161. Daniulaityte, R.; Carlson, R.; Falck, R.; Cameron, D.; Perera, S.; Chen, L.; Sheth, A. “I just wanted to tell you that loperamide WILL WORK": A web-based study of the extra-medical use of loperamide. Drug Alcohol Depend. 2013, 130, 241-244. [CrossRef] [PubMed]

162. Grey Pages: The Merits of High Dose Loperamide for Opiate Withdrawal. Available online: http:/ / derekwmeyer. blogspot.com/2012/03/merits-of-high-dose-loperamide-for.html (accessed on 30 November 2017).

163. Finch, M. How to Use Loperamide for Opiate Withdrawal. 2015. Available online: http:/ / opiateaddictionsupport. com/how-to-use-loperamidefor-opiate-withdrawal/ (accessed on 30 November 2017).

164. Levine, D.A. "Pharming": The abuse of prescription and over-the-counter drugs in teens. Curr. Opin. Pediatr. 2007, 19, 270-274. [CrossRef] [PubMed]

165. Cooper, R.J. Over the counter medicine abuse-A review of the literature. J. Subst. Use 2013, 18, 82-107. [CrossRef] [PubMed]

166. Fox, N.; Ward, K.; O'Rourke, A. The birth of the e-clinic. Continuity or transformation in the UK governance of pharmaceutical consumption? Soc. Sci. Med. 2005, 61, 1474-1484. [CrossRef] [PubMed]

167. Manchikanti, L. Prescription drug abuse: What is being done to address this new drug epidemic? Testimony before the Subcommittee on Criminal Justice, Drug Policy and Human Resources. Pain Physician 2006, 9 , 287-321. [PubMed]

168. National Association of Board of Pharmacy (NABP). Buying Medicine Online. Available online: https: //nabp.pharmacy/initiatives/dot-pharmacy/buying-medicine-online/ (accessed on 11 November 2017).

169. Food and Drug Administration (FDA) Imodium Label. Available online: https:/ /www.accessdata.fda.gov / drugsatfda_docs/label/2016/017690s005lbl.pdf (accessed on 28 January 2018).

170. Baker, D.E. Loperamide: A pharmacological review. Rev. Gastroenterol. Disord. 2007, 7 (Suppl. 3), S11-8. [PubMed]

171. Jaffe, J.H.; Kanzler, M.; Green, J. Abuse potential of loperamide. Clin. Pharmacol. Ther. 1980, 28, 812-819. [CrossRef] [PubMed]

172. Wightman, R.S.; Hoffman, R.S.; Howland, M.A.; Rice, B.; Binary, R.; Lugassy, D. Not your regular high: Cardiac dysrhythmias caused by loperamide. Clin. Toxicol. 2016, 54, 454-458. [CrossRef] [PubMed]

173. Borron, S.W.; Watts, S.H.; Tull, J.; Baeza, S.; Diebold, S.; Barrow, A. Misuse and Abuse of Loperamide: A New Look at a Drug with "Low Abuse Potential”. J. Emerg. Med. 2017, 53, 73-84. [CrossRef] [PubMed]

174. Marraffa, J.M.; Holland, M.G.; Sullivan, R.W.; Morgan, B.W.; Oakes, J.A.; Wiegand, T.J.; Hodgman, M.J. Cardiac conduction disturbance after loperamide abuse. Clin. Toxicol. 2014, 52, 952-957. [CrossRef] [PubMed]

175. Food and Drug Administration (FDA) Drug Safety Communications. FDA Warns about Serious Heart Problems with High Doses of the Anti-Diarrheal Medicine Loperamide (Imodium), Including from Abuse and Misuse. Safety Announcement. 6 July 2016. Available online: https://www.fda.gov/Drugs/ DrugSafety/ucm504617.htm (accessed on 22 November 2017).

176. New York Times. Addicts Who Can't Find Painkillers Turn to Anti-Diarrhea Drugs. 10 May 2016. Available online: https:/ /www.nytimes.com/2016/05/11/health/imodium-opioid-addiction.html?_r=0. (accessed on 24 November 2017).

177. Stanciu, C.N.; Gnanasegaram, S.A. Loperamide, the "Poor Man's Methadone": Brief Review. J. Psychoact. Drugs 2017, 49, 18-21. [CrossRef] [PubMed]

178. Eggleston, W.; Marraffa, J.M.; Stork, C.M.; Mercurio-Zappala, M.; Su, M.K.; Wightman, R.S.; Cummings, K.R.; Schier, J.G. Notes from the Field: Cardiac Dysrhythmias after Loperamide Abuse-New York, 2008-2016. MMWR Morb. Mortal Wkly. Rep. 2016, 65, 1276-1277. [CrossRef] [PubMed]

179. Eggleston, W.; Clark, K.H.; Marraffa, J.M. Loperamide Abuse Associated With Cardiac Dysrhythmia and Death. Ann. Emerg. Med. 2017, 69, 83-86. [CrossRef] [PubMed]

180. Bhatti, Z.; Norsworthy, J.; Szombathy, T. Loperamide metabolite-induced cardiomyopathy and QTc prolongation. Clin. Toxicol. 2017, 55, 659-661. [CrossRef] [PubMed] 
181. Kozak, P.M.; Harris, A.E.; McPherson, J.A.; Roden, D.M. Torsades de pointes with high-dose loperamide. J. Electrocardiol. 2017, 50, 355-357. [CrossRef] [PubMed]

182. Wu, P.E.; Juurlink, D.N. Clinical Review: Loperamide Toxicity. Ann. Emerg. Med. 2017, 70, $245-252$. [CrossRef] [PubMed]

183. Bishop-Freeman, S.C.; Feaster, M.S.; Beal, J.; Miller, A.; Hargrove, R.L.; Brower, J.O.; Winecker, R.E. Loperamide-Related Deaths in North Carolina. J. Anal. Toxicol. 2016, 40, 677-686. [CrossRef] [PubMed]

184. Swank, K.A.; Wu, E.; Kortepeter, C.; McAninch, J.; Levin, R.L. Adverse event detection using the FDA post-marketing drug safety surveillance system: Cardiotoxicity associated with loperamide abuse and misuse. J. Am. Pharm. Assoc. 2017, 57, S63-S67. [CrossRef] [PubMed]

185. Church, J.; Fletcher, E.J.; Abdel-Hamid, K.; MacDonald, J. Loperamide blocks high-voltage-activated calcium channels and N-methyl-D-aspartate-evoked responses in rat and mouse cultured hippocampal pyramidal neurons. Mol. Pharmacol. 1994, 45, 747-757. [PubMed]

186. Nozaki-Taguchi, N.; Yaksh, T.L. Characterization of the antihyperalgesic action of a novel peripheral mu-opioid receptor agonist- loperamide. Anesthesiology 1999, 90, 225-234. [CrossRef] [PubMed]

187. Kang, J.; Compton, D.R.; Vaz, R.J.; Rampe, D. Proarrhythmic mechanisms of the common anti-diarrheal medication loperamide: Revelations from the opioid abuse epidemic. Naunyn Schmiedebergs Arch. Pharmacol. 2016, 389, 1133-1137. [CrossRef] [PubMed]

188. Zhou, S.; Lim, L.Y.; Chowbay, B. Herbal modulation of P-glycoprotein. Drug Metab. Rev. 2004, 36, 57-104. [CrossRef] [PubMed]

189. Loperamide + Black Pepper Exctract $=$ Feeling Really Nice. Available online: www.erowid.com (accessed on 3 January 2018).

190. Corazza, O.; Assi, S.; Simonato, P.; Corkery, J.M.; Bersani, F.S.; Demetrovics, Z.; Stair, J.; Fergus, S.; Pezzolesi, C.; Pasinetti, M.; et al. Promoting innovation and excellence to face the rapid diffusion of novel psychoactive substances in the EU: The outcomes of the ReDNet project. Hum. Psychopharmacol. 2013, 28, 317-323. [CrossRef] [PubMed]

191. Larsen, T.R.; McMunn, J.; Ahmad, H.; AlMahameed, S.T. Ventricular Tachycardia Triggered by Loperamide and Famotidine Abuse. Drug Saf. Case Rep. 2018, 5, 11. [CrossRef] [PubMed]

192. Sehring, M.; Chambers, J. Letter to the editor. Loperamide abuse and cardiotoxicity. J. Community Hosp. Intern. Med. Perspect. 2017, 7, 275. [CrossRef]

193. Orsolini, L.; Papanti, G.D.; Francesconi, G.; Schifano, F. Mind navigators of chemicals' experimenters? A web-based description of e-psychonauts. Cyberpsychol. Behav. Soc. Netw. 2015, 18, 296-300. [CrossRef] [PubMed]

194. Johanson, C.E.; Balster, R.L.; Henningfield, J.E.; Schuster, C.R.; Anthony, J.C.; Barthwell, A.G.; Coleman, J.J.; Dart, R.C.; Gorodetzky, C.W.; O'Keeffe, C.; et al. Risk management post-marketing surveillance for the abuse of medications acting on the central nervous system: Expert panel report. Drug Alcohol Depend. 2009, 105 (Suppl. 1), S65-S71. [CrossRef] [PubMed]

195. Mackey, T.K.; Nayyar, G. Digital danger: A review of the global public health, patient safety and cybersecurity threats posed by illicit online pharmacies. Br. Med. Bull. 2016, 118, 110-126. [CrossRef] [PubMed]

196. McColl, S.; Sellers, E.M. Research design strategies to evaluate the impact of formulations on abuse liability. Drug Alcohol Depend. 2006, 83 (Suppl. 1), S52-S62. [CrossRef] [PubMed]

197. FDA's Role in Preventing Prescription Drug Abuse. Statement of Robert J. Meyer, M.D. before the House Committee on Government Reform, September 13, 2005. Available online: http:/ /www.fda.gov / NewsEvents/Testimony/ucm112718.htm (accessed on 30 November 2017).

198. Schifano, F.; Papanti, G.D.; Orsolini, L.; Corkery, J.M. The consequences of drug misuse on post-marketing surveillance. Exp. Rev. Clin. Pharmacol. 2016, 9, 867-871. [CrossRef] [PubMed]

(C) 2018 by the authors. Licensee MDPI, Basel, Switzerland. This article is an open access article distributed under the terms and conditions of the Creative Commons Attribution (CC BY) license (http:// creativecommons.org/licenses/by/4.0/). 